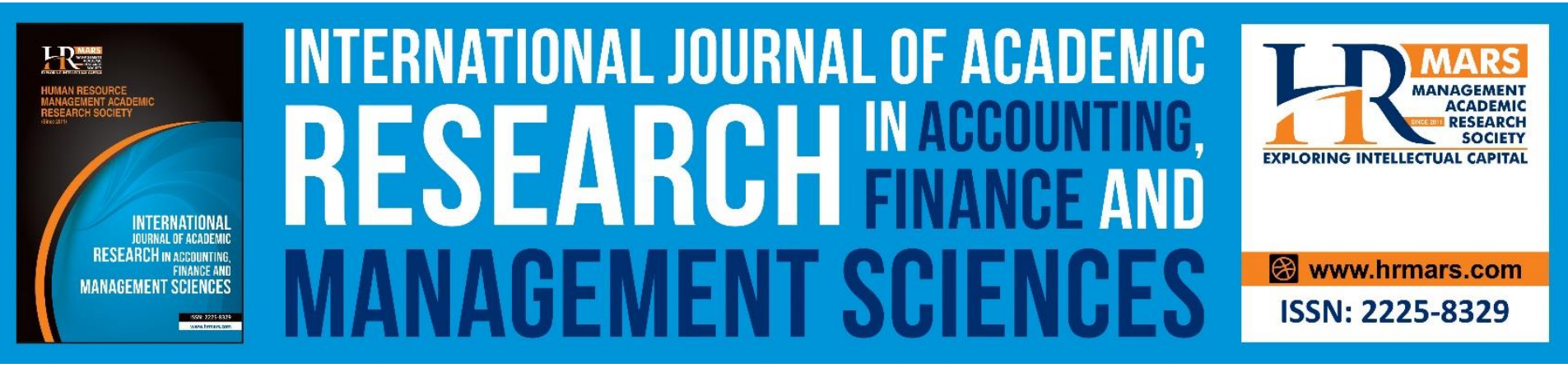

\title{
Retrenchment Strategy and Firm Performance: Evidence from Malaysian Construction Companies
}

\section{Ameer Eizzuan Abdul Jamal, Mohd Shamlie Salisi}

To Link this Article: http://dx.doi.org/10.6007/IJARAFMS/v11-i1/8001 DOI:10.6007/IJARAFMS/v11-i1/8001

Received: 19 December 2020, Revised: 21 January 2021, Accepted: 09 February 2021

Published Online: 28 February 2021

In-Text Citation: (Jamal \& Salisi, 2021)

To Cite this Article: Jamal, A. E. A., \& Salisi, M. S. (2021). Retrenchment Strategy and Firm Performance: Evidence from Malaysian Construction Companies. International Journal of Academic Research in Accounting Finance and Management Sciences, 11(1), 120-138.

Copyright: (C) 2021 The Author(s)

Published by Human Resource Management Academic Research Society (www.hrmars.com)

This article is published under the Creative Commons Attribution (CC BY 4.0) license. Anyone may reproduce, distribute, translate and create derivative works of this article (for both commercial and non-commercial purposes), subject to full attribution to the original publication and authors. The full terms of this license may be seen at: http://creativecommons.org/licences/by/4.0/legalcode

Vol. 11, No. 1, 2021, Pg. 120 - 138

Full Terms \& Conditions of access and use can be found at http://hrmars.com/index.php/pages/detail/publication-ethics 


\title{
Retrenchment Strategy and Firm Performance: Evidence from Malaysian Construction Companies
}

\author{
Ameer Eizzuan Abdul Jamala ${ }^{a}$ Mohd Shamlie Salisi $^{\mathrm{b}}$ \\ a MSc Candidate, b Senior Lecturer, a, b Faculty of Business and Management, Universiti Teknologi \\ MARA, Kota Kinabalu 88997, Sabah, Malaysia. \\ Email: ameer5200@gmail.com
}

\begin{abstract}
With the latest Gross Domestic Product (GDP) rate of $4.7 \%$ form the $4^{\text {th }}$ Quarter of 2018 which shows an uprising trend in the Malaysian economy, it is no exception for managers to implement a strategy due to the order from the higher authorities which us to conduct a retrenchment strategy. This order falls toward specific sectors such as manufacturing, financial services and construction sector which is to be done to increase firm performance. With the construction sector that is more likely to be listed in PN17 (Amir Hisyam,2018) it gives more attention for the researcher to focus more on the sector with it being the second highest rate of loss of employment in Malaysia. Hence this research aims to investigate the relationship between retrenchment strategy and firm performance for a sample of 49 listed construction companies in Malaysia which is to be chosen if the firms has the following criteria that needed by this study over the period of 2008-2018. Afterwards this study will investigate the effects of the firm performance towards potential investor's decision as the contributing component of this study is implementing Return on Equity as well as Tobin's $Q$ in the dependent variable. By using regression model in STATA software alongside with multiple tests to examine the data of the firms, the study hopes to find acceptable results to determine the relationship among the variables. Later in the study the results show that the main variable which is retrenchment has no significant influence towards any of the firm performance. The study will contribute to Malaysia construction firms, investors and managers by showing how in the current state of the country does practicing retrenchment strategy affects the firm performance.
\end{abstract}

Keywords: Retrenchment Strategy, Firm Performance.

\section{Introduction}

\section{Retrenchment}

In order to survive a business from contributing towards economy downfall, each and different firms have many capabilities. Strategic management and finance literatures documented that retrenchment strategy is one way to keep firms afloat against the roaring tide (Ung et al, 2018). Retrenchment strategy is a common strategy used by organizations in facing bad financial 
INTERNATIONAL JOURNAL OF ACADEMIC RESEARCH IN ACCOUNTING, FINANCE AND MANAGEMENT SCIENCES

Vol. 11, No. 1, 2021, E-ISSN: 2225-8329 @ 2021 HRMARS

performance (Morrow et al., 2004; Ung et al., 2018). It is operationalized to reduce the risk of loss by selling the assets and eliminating sticky fixed cost. Although commonly imposed by companies, retrenchment is rarely investigated as empirical research (Lik-Jing, 2018).

Moreover, studies on the relationship between firm strategy and firm performance are dominated by a turnaround strategy (e.g., Khanna \& Palepu, 2000; Denis et al., 2002; Lins \& Servaes, 2002, Fauver et al., 2004; Lee et al., 2012). Turnaround strategy generally defines as the process of transforming a los-making company into a profit-making company. Anastasia (2015) states that corporations may perform this strategy in cases such as when the business is experiencing downturn events. This strategy is a method towards corporate renewals which is aiming to save a troubled-corporations such as those that are listed under PN17 or PN4 which indicates that the companies listed are experiencing downturn performance and in need of corporate recovery.

Anastasia (2015) also stated the external causes for failing companies such as new aggressive competitor, increase in prices of supply, changes in the market demand and economic conditions. For this study, it is suitable to look at economic conditions as the problem will be explain in the problem statement in page 4. Economic conditions as explained by Anastasia (2015) is the current condition of the market or economy could be a contributing factor to the decline of a company.

This research defines retrenchment as a reduction in assets and costs. Furthermore, retrenchment also consists of reduction of the finished goods and inventory, reduction of the number of employees, reduction of selling, general, and administrative expenses (SGA), reduction of plant, property, and equipment costs (PPE), and reduction of research and development costs (R\&D) (Hofer, 1980; Morrow et al., 2004; David, 2013). For example, selling off inefficient and underutilized assets might help firms to perform better in declining economy (Schendel et al.1976; Hambrick \& Schecter 1983; O’Neill 1986; Lim et al., 2013).

Meanwhile, Malaysian firms offer a good platform for further exploration of this topic due to its high degree of retrenchment. For example, retrenchment strategy such as lay-offs, selling off the property, and also including the closure of plant that was conducted by Malaysian companies will probably have different outcomes. Take Malaysia Airlines for example, where the firm were restructured and privatized in order to ensure the air carrier would remain operating after the crisis of $\mathrm{MH} 370$ and $\mathrm{MH} 17$. Other companies such as Tesco Malaysia also announced to plan restructure to the company as well as standardizing job grading to make the company more profitable. Yet, each company has taken different benefit and cost that incurred from retrenchment strategy.

Furthermore, Malaysia also provides a unique institutional setting to examine the performance of retrenchment with its interesting pyramiding and crossholding controlling shareholder issue. For instance, Firm A might be controlled by the owner of Firm B, where Firm B is controlled by owner of Firm C. Yet, Firm C is controlled back by owner of Firm A. Interestingly, those owners are from one family business groups. This scenario provides different insights into the literature of this research area of retrenchment Ung, Brahmana, \& Puah, (2018).

(Donovan, 2016) states the situation that can make a company retrench an employee. Companies may decide on a business strategy when the company is suffering any losses in order to minimize of poor economic conditions. For instance, laying off or terminating some employees and outsourcing their positions to third parties to reduce costs. Such strategy has been accepted by the courts for being a genuine strategy as it is the employer's burden for making the strategy as genuine as possible. 
However, the circumstances upon dismissing employees before coming to a conclusion as to whether the dismissal was fair or not will still be examine by the court (Donovan, 2016).

In addition to further relate to this study, construction sector in Malaysia is rated as the second highest sector to retrench their employees in the year 2018 as can be seen in figure 1.1 below alongside as some companies in the sector is deemed to be listed under PN17 which are companies that are suffering financial crisis, Amir (2018).

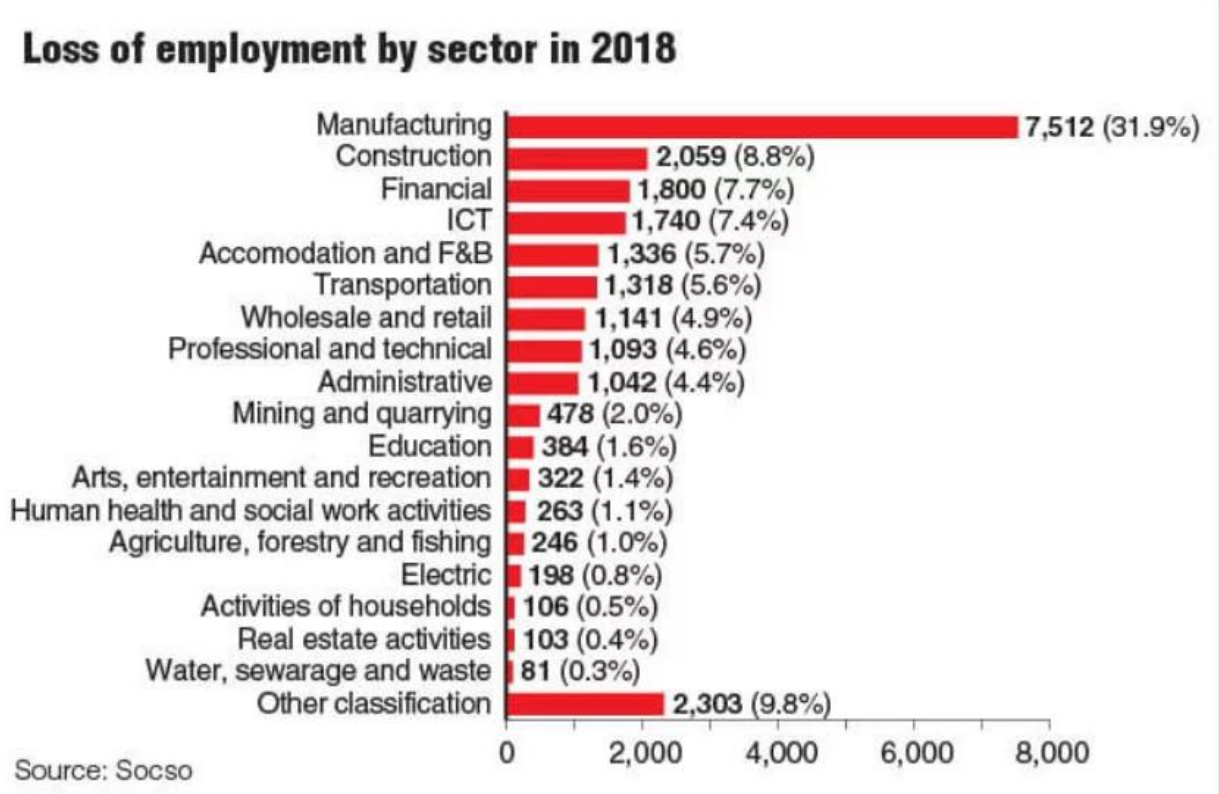

Figure 1 Loss of Employment

Finally, this research contributes to the body of knowledge and policymakers in two ways. Firstly, it adds to the literature by exploring the association between firm performance and firm strategy. Whereby this study is different from prior research when it uses retrenchment strategy as the main variable. Hence, the relationship between firm performance and retrenchment strategy is a relatively new topic and has received less attention from researchers compared to other strategies such as diversification and Merger and Acquisition.

Secondly, this study contributes to the literature by extending the understanding of this research area to less developed markets, such as Malaysia. Whereby, the findings of this research can be used as a benchmark or guideline for similar future researches with similar market contexts like developing markets. Therefore, this study aims to examine empirically firm performance in imposing retrenchment strategy in a relatively less developed or developing market like Malaysia.

\section{Problem Statement}

With the current uprising trend of the Malaysia's gross domestic product (GDP) which grew $4.7 \%$ year-on-year (y-o-y) by the fourth quarter of 2018, every business firm is expected to run smoothly by contributing to the economy uprising trend. However, during the year 2018, a new $14^{\text {th }}$ General Election (GE14) was conducted and the Malaysian economy is now running under new government which arises several issues.

For instance, when Malaysian Trades Union Congress (MTUC) President, Abdul Halim Mansor, was informed by the Labour Department that 30,000 to 50,000 people could be retrenched in 2018 and 
INTERNATIONAL JOURNAL OF ACADEMIC RESEARCH IN ACCOUNTING, FINANCE AND MANAGEMENT SCIENCES

Vol. 11, No. 1, 2021, E-ISSN: $2225-8329$ @ 2021 HRMARS

forecasted for the year after. This number of expected lay-offs arises from past decision with the mean of 32,000 employees retrenched in 2015 to 2017.

In addition, Malaysian Employers Federation (MEF) Executive Director, Datuk Shamsudin Baradan, informed that the main sector to be affected will be manufacturing, followed by the services sectors of insurance, banking and retail and the construction sector, due to the economic situation. This situation which based on both laid-off employees and employers on how the strategy would affect on the firm's performance has invited a new are of research interest.

There are few researches had been done about retrenchment strategy relating towards firm's performance and most of them only measures the strategy towards profitability of the company (Return on Asset). Examples from Ung, Brahmana, \& Puah, (2018); Bhutto (2018); Pham (2016); Imran (2014). Future studies should include both accounting-based and market-based measurement as suggested by Imran (2014).

Hence, this study contributes by measuring retrenchment strategy towards not only profitability, but also to financial performance (Return on Equity) and Tobin's $Q$ which is the ratio between a physical asset's market value and its replacement value. Other than that, this study also contributes on focusing towards specific sector of construction companies which are public listed under government data for most retrenchment of employees since 1998 until the latest of $4^{\text {th }}$ Quarter of 2018 in Bursa Malaysia.

Furthermore, as construction companies have been only focusing on getting their projects approved or reapproved by the new government, and due to that a bulk hiring has been slow since May 2018 whereby, with the extended deadlines of contracts, they can hire fewer labour for a long period project (Chua, 2019). In addition, the announcement of retrenchments for the sectors regardless for the manufacturing sector which has the biggest number of employee lay-off among the other sectors, had been done by other researchers whereby in their study, retrenchment strategy may harm the performance of family and government-linked firms (e.g. Ung, Brahmana, \& Puah (2018).

Other than that, most studies conducted focuses more on organizational performances, from where it lacks information on how it affects the firm market performance or finances (e.g. Ung, Brahmana, \& Puah (2018); Bhutto (2018); Pham (2016); Imran (2014).

Hence, the question arises on how retrenchment strategy affects firm performance in the matter of market value, organization and financial as this could provide more information towards potential investors to monitor the sector's Return on Equity and market value. Therefore, this study seeks to investigate whether the performance of listed construction companies in Malaysia will be affected by the retrenchment strategy?

\section{Research Objectives}

As similar study has been done by other researchers such as Ung, Brahmana, \& Puah (2018); Hillier et al., (2007), this research is also structured with some important objectives in establishing a research paper. The purpose of providing these objectives so that this study can be conducted in line with the purpose and research proposal and to be drafted in a good structure.

R01: To identify the relationship between retrenchment strategy and the performance of listed construction companies in Malaysia.

RO2a: To identify the relationship between size strategy and the performance of listed construction companies in Malaysia. 
INTERNATIONAL JOURNAL OF ACADEMIC RESEARCH IN ACCOUNTING, FINANCE AND

MANAGEMENT SCIENCES

Vol. 11, No. 1, 2021, E-ISSN: 2225-8329 @ 2021 HRMARS

RO2b: To identify the relationship between growth opportunity strategy and the performance of listed construction companies in Malaysia.

RO2c: To identify the relationship between leverage strategy and the performance of listed construction companies in Malaysia.

\section{Literature Review}

\section{Agency Cost Theory}

There are only few studies that had been done when relating retrenchment strategy towards firm performance with agency cost theory. Robert T. Kleiman is one the available source that is able to relate the topic with agency theory in his article.

Robert stated that since agency relationships in a corporation is complex than any contractual relationships due to the terms of agents being required to do tasks for the principal, agency theory carries with specific ethical issues and problems as it concerned both parties (agents and principal). The traditional process of agency contracts assumes that agents such as managers should always act in principal's interest, presuming the owners. Jensen and Meckling (1976) and Baker and Anderson (2010) explain that the agency problem arises when company managers attempt to maximize and fulfill their interest at shareholders' expense.

In the matter of retrenchment or lay-off in large corporations, Robert stated that investors are rewarded when companies decreased their employees because operating costs are lowered, which in theory may lead to better profits. However, whenever there is news regarding retrenchment being practiced, it also highlights whether investors are pleased or not with the announcement of mass layoff. This theory assumes that management undertaking the layoffs whether in part or whole, has the objectives to please shareholders and to maximize their wealth.

In this instance it's obvious that shareholders' interests are advanced to the harm of a minimum of one different body, particularly the workers. In such cases, question arises on whether it is to serve the principals' interests when those actions harm a large number of people, and whether the benefits shareholders receive are commensurate with the harm inflicted on the laid-off employees, as stated by Robert. He also mentioned that traditional agency theory makes fewer facts of what obligations, moral and etc., principals have towards their agents, as it was noted by some observers.

The emphasis lies solely on the agents discussing what they should or must do for the principal with relying assumptions that principals will compensate agents adequately for their services. Some scholars argued that principals have obligations as well. By using the example above regarding laying off employees, some would argue that those actions are unethical which is harming the workers in order to obtain better performance regarding with maximizing shareholder's wealth.

Being in line with the agency theory, agents are noticed as to have ethical duties to the principals. If in any case with a negative assumption whereby managers act in self-interest and fails to satisfy the interests of the shareholders, it shows a declining state of ethical responsibilities according to some views such as Robert. Agency theory also shows there is a possibility manager imposes retrenchment as the shortcut to pertain their position, and part of showing their power as an outcome of pride and self- esteem. (Anderson and Reeb, 2003). 
INTERNATIONAL JOURNAL OF ACADEMIC RESEARCH IN ACCOUNTING, FINANCE AND

MANAGEMENT SCIENCES

Vol. 11, No. 1, 2021, E-ISSN: 2225-8329 ๔ 2021 HRMARS

\section{Accounting-Based Measurements}

For company's profitability, by comparing to the benchmarked rate of return equalling to the risk adjusted weighted average cost of capital, Accounting-based measurement is considered to be an effective indicator as it consists of Return on Assets, Return on Equity and others such as Return on Investment and Earnings per share, Al-Matari et al (2014). Kapopoulos \& Lazaretou, (2007) stated that the accountant is the one who is measuring the rate of profit with the limitation by standards established by the profession and due to that it affected the accounting practices such as the various methods for the assaements of tangible and non-tangible assets.

Return on Assets (ROA) measures the operating and financial performance of the firm as stated by Klapper \& Love, (2002). As mentioned by Haniffa \& Huduib, (2006), the measurement of ROA is when a company has a higher ROA, it shows that the effectiveness of the company for the use of assets to the advantage of the shareholders. Other than that, it also reflects the company's effectiveness of using assets in serving the economic interests of its shareholders (Ibrahim \& AbdulSamad, 2011).

Return on Equity (ROE) however, is a measure of financial performance calculated by dividing net income by shareholder's equity - Investopedia. This financial ratio will be able to tell investors whether the company interested is a profit creator or a profit burner. Researcher Imran (2014) seemed the only one that made a study on retrenchment strategy affecting to only ROE which has a significant relationship. This shows the contribution of the researcher of this study to add more findings towards this financial ratio due to the lack of studies.

\section{Market-Based Measurements}

Tobin's Q ratio, created by James Tobin, is listed under the Market-Based Measurements whereby as it was stated that, the ratio indicates the value of the firm's market. The Market-Based Measurement is classified by the forward-looking aspect and its reflection of the expectations of the shareholders concerning the firm's future performance (Wahla, ShahSyed \& Hussain, 2012; Shan \& Mclver Ron, 2011; \& Ganguli \& Agrawal, 2009). The Q Ratio refers to a traditional measure of expected long-run firm performance (Bozec, Dia \& Bozec, 2010). James hypothesized that the combination market value of all the companies on the stock market should be about equal to their replacement costs.

The other reason as to question of choosing this ratio as a proxy is mainly due to the lack of studies being made when it comes to retrenchment strategy affecting firm performance, specifically towards the Tobin's $Q$. This is mainly due to the favour of researchers finding results of firm performance from corporate governance. Such studies regarding the effect from retrenchment strategy are from Ung, Brahmana, \& Puah (2018); Pham (2016), whereby their results show the same outcome whereby the strategy has significant relationship with the $Q$ Ratio. Contradict to (Zetun and Tian, 2007) whereby the outcome shows the opposite.

\section{Retrenchment}

Despite the abundance of literature on retrenchment-performance, there is little agreement on whether imposing retrenchment strategy may give a positive, negative, or no relationship with firm performance. Thus far, many empirical studies conducted to investigate the firm benefits of retrenchment strategy have yielded inconsistent results. The earlier studies on retrenchment were mostly conducted for firms from developed countries, and only later extended to other few emerging countries. 
This study defines retrenchment as reduction in assets and costs. It includes the reduction of the finished goods and inventory, the reduction of the number of employees, the reduction of selling, selling, general, and administrative expenses (SGA), the reduction of plant, property, and equipment costs (PPE), and the reduction of research and development costs (R\&D) (Morrow et al., 2004; Schmitt \& Raisch, 2013). According to David (2013), firms use retrenchment when an organization regroups through cost and asset reduction in order to help declining performance. Retrenchment includes selling off land and buildings, cutting the number of employees, knocking off product lines, discontinuing the marginal businesses, and closing obsolete factories.

Previous literatures have documented that retrenchment strategy might induce firm performance in two ways: (i) asset retrenchment, and (ii) cost retrenchment (Morrow et al., 2004; Lim et al., 2013). Asset retrenchment refers to the net reduction of assets (Robbins and Pearce, 1992), such as closing plants, divesting equity and reducing stocks of property, equipment, and inventory (Morrow et al., 2004; Lim et al., 2013). Meanwhile, cost retrenchment refers to the net reduction of total costs such as Selling, General, and Administrative (SGA) expenses, interest expense and miscellaneous costs. (Robbins and Pearce, 1992; Lim et al., 2013). Morrow et al., (2004) argues that firms throw all their less effective and less productive assets in order to improve the performance.

\section{Controlled Variables}

This study adopted previous research baseline model which consists of firm performance factors such as firm size, growth opportunity, leverage and profitability Liang \& Barker, 2010; Lee et al., 2012; Lim et al., 2013; Schmitt \& Raisch, 2013). However, the researcher will exclude the variable profitability in order to avoid any redundancy which a profit variable is measuring a profit ratio of performance. Therefore, it leaves out with adopting the firm performance factors of firm size, growth opportunities and leverage.

\section{Firm Size}

Firm size is measured by total assets logarithm. (Agrawal \& Knoeber, 1996; Klapper \& Love, 2004) states that a large firm size can lead to significant growth opportunities. This latter will positively affect firm performance. However, Brian, Mcllkenny, Opong and Pignatel (2014) suggest that a large firm size may create significant agency conflicts between managers and owners, which will negatively influence firm performance.

\section{Growth Opportunities}

Growth opportunities are measured by the Market-To-Book ratio. Baber et al. (1996) and Gul (1999) suggest a negative relationship between growth opportunities and firm performance. An increase in growth opportunities may lead to a retrenchment in managerial behaviour (Gaver \& Gaver, 1993; Skinner, 1993; Smith \& Watts, 1992). However, the existence of growth opportunities can lead to profitable investment projects, which will positively affect firm performance.

\section{Leverage}

Debt to equity ratio is very important ratio to measure the financial leverage. This ratio shows that how much companies use debts to operate its financial activates. It also shows the relationship of 
debts and the value of equity. Debt equity ratio use by (Tugas, 2012), (Opter Tim, 2009) and (Vale, 2011) under their studies.

\section{Conceptual Framework and Hypotheses}

Conceptual framework mainly explains how particular variables such independent variables which is in this study consists of the main variable of retrenchment followed by the controlled variables of size, growth opportunity and leverage connecting towards the dependent variables of firm performance which are Return on Assets (ROA), Return on Equity (ROE) and Tobin's Q.

The ROA is mainly measured for the use of managers to monitor their profitability performance of the company, whereas for the contributing variables of this study which are ROE and Tobin's $Q$ are mainly measured for investors to monitor in order to make good or cautious decisions. 
INTERNATIONAL JOURNAL OF ACADEMIC RESEARCH IN ACCOUNTING, FINANCE AND MANAGEMENT SCIENCES

Vol. 11, No. 1, 2021, E-ISSN: 2225-8329 @ 2021 HRMARS

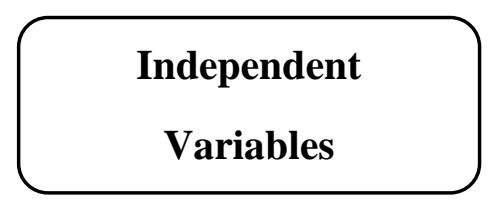

\section{Dependent \\ Variables}

H1: Retrenchment

[a] Return on Asset

H2: Firm Size

[b] Return on Equity

H3: Growth

Opportunity

H4: Leverage

[c] Tobin's Q

Figure 2 Conceptual Framework 
From the framework above, this study hypothesizes:

$\mathrm{H1a}$ : There is a relationship between retrenchment strategy and the Return on Asset performance of listed construction companies in Malaysia.

$\mathrm{H} 1 \mathrm{~b}$ : There is a relationship between retrenchment strategy and the Return on Equity performance of listed construction companies in Malaysia.

$\mathrm{H} 1 \mathrm{c}$ : There is a relationship between retrenchment strategy and the Tobin's $Q$ performance of listed construction companies in Malaysia.

$\mathrm{H} 2 \mathrm{a}$ : There is a relationship between firm size and the Return on Asset performance of listed construction companies in Malaysia.

$\mathrm{H} 2 \mathrm{~b}$ : There is a relationship between firm size and the Return on Equity performance of listed construction companies in Malaysia.

$\mathrm{H} 2 \mathrm{c}$ : There is a relationship between firm size and the Tobin's $Q$ performance of listed construction companies in Malaysia.

$\mathrm{H} 3 \mathrm{a}$ : There is a relationship between growth opportunity and the Return on Asset performance of listed construction companies in Malaysia.

$\mathrm{H} 3 \mathrm{~b}$ : There is a relationship between growth opportunity and the Return on Equity performance of listed construction companies in Malaysia.

$\mathrm{H} 3 \mathrm{c}$ : There is a relationship between growth opportunity and the Tobin's $Q$ performance of listed construction companies in Malaysia.

$\mathrm{H} 4 \mathrm{a}$ : There is a relationship between leverage and the Return on Asset performance of listed construction companies in Malaysia.

$\mathrm{H} 4 \mathrm{~b}$ : There is a relationship between leverage and the Return on Equity performance of listed construction companies in Malaysia.

$\mathrm{H} 4 \mathrm{c}$ : There is a relationship between leverage and the Tobin's Q performance of listed construction companies in Malaysia.

\section{Research Methodology}

This study will use the secondary data from annual published financial statements of all construction companies in Malaysia for every year since the data are considered reliable and the financial statements are prepared based on standardized accounting principles in every industry. The data that will be used are the annual time series from the Statement of Financial Position, Statement of Profit and Loss, Profit value and risk Ratio and Ratio Key Metrix of listed construction companies from 2008 to 2018. The data will be gathered for 49 construction companies in Malaysia and all dependent variable and independent variables data will be sourced from Bursa Malaysia website.

Quantitative approach will be adopted in order to test the relationship between the independent variables and dependent variable. This is because the quantitative approach is more suitable to analyse the data and make general conclusions from the large quantities of data.

The outcomes produced then functionally as an indicator of the firm's performance. In order to test and analyse the retrenchment variables in this study, secondary data will be used to measure the firm's performance and the variables of retrenchment. All the data will be collected from database Bursa Malaysia, Datastream and MorningStar for the companies listed in Bursa Malaysia under construction sectors. 
INTERNATIONAL JOURNAL OF ACADEMIC RESEARCH IN ACCOUNTING, FINANCE AND MANAGEMENT SCIENCES

Vol. 11, No. 1, 2021, E-ISSN: 2225-8329 @ 2021 HRMARS

\section{Samples}

This study will concentrate on listed construction companies which is provided in Bursa Malaysia whereby there are total of 72 companies stated in the system. However, there are multiple same companies that are listed under those 72 companies as these companies published their warrant statements separately. Due to that, the researcher will be only focusing on 49 construction companies that are only publishing financial statements as that is the main statements that will be focusing on.

The time period that will be monitored is from 2008 until 2018. The reason for the specific period is due from the global crisis that hit Malaysia in 2008 up to the second quarter of 2009 which affected in major retrenchment decision, making construction sector the second highest sector to have retrenched employees, Department of Statistics (2009). The trend follows afterwards with the sector constantly retrenching employees up to 2018 while still being listed as the second highest sector to retrenched their staffs.

\section{Variables}

Following previous research, the baseline model of this research consists of firm performance factors, such as firm size, growth, leverage, and profitability (Hambrick \& D’Aveni, 1988; Lu \& Beamish, 2001; Morrow et al., 2004; McClelland et al., 2010; Lee et al., 2012; Lim et al., 2013; Schmitt \& Raisch, 2013). The size of firms (SIZE) is measured using the log of total assets. Meanwhile, growth opportunity (GROWTH) is measured by the capital expenditure to sales ratio. The profitability is measured by the operating income to sales ratio (OIS), and leverage (LEV) is measured by using the ratio of debt to common share equity. Our baseline model is given as follows.

To estimate the above model empirically, we pooled all samples and estimate the following regression model:

\begin{tabular}{|c|}
\hline Firm Performance $=f($ size, growth opportunity, profitability, leverage $)$ \\
\hline Performance $_{i t}=\beta_{0}+\beta_{1}$ Size $_{i t}+\beta_{2}$ Ois $_{i t}+\beta_{3}$ Growth $_{i t}+\beta_{4} L^{2} v_{i t}+\sum_{i t}$ \\
\hline
\end{tabular}

Where:

Performance $=$ Firm Performance

SIZE $=$ the log of assets or the firm size

$\mathrm{OIS}=$ the ratio of operating income- sales ratio

GROWTH = the capital expenditure-sales ratio

$\mathrm{LEV}=$ the ratio of debt to common share equity

However, since this study also discusses about affecting profitability performance, it is suitable to remove the Ois or profitability ratio from the model as to avoid any problem to be encountered. Therefore, the model shall be modified by eliminating the profitability variable.

$$
\text { Performance }_{i t}=\beta_{0}+\beta_{1} \text { Size }_{i t}++\beta_{2} \text { Growth }_{i t}+\beta_{3} \text { Lev }_{i t}+\sum_{i t}
$$


INTERNATIONAL JOURNAL OF ACADEMIC RESEARCH IN ACCOUNTING, FINANCE AND MANAGEMENT SCIENCES

Vol. 11, No. 1, 2021, E-ISSN: 2225-8329 @ 2021 HRMARS

\section{Results}

In the early stages of data analysing it show that the dependent variables of Return on Asset (ROA) and Return on Equity (ROE) has heteroscedasticity problem with no problem of serial correlation and in order to solve that problem, Robust Standard Error Test will be conducted.

Different scenario however for Tobin's $Q$, the $p$-value of the Wooldridge Test is 0.0000 which is less than 0.05 and it indicates that for Tobin's $Q$ there is serial correlation problem. Since Tobin's $Q$ has both serial correlation and heteroscedasticity problem, Feasible generalized least squares test will be conducted to rectify the problem. Below are the final results analysed.

Table 1 Linear Regression Return on Asset (Robust)

\begin{tabular}{|l|l|l|l|l|l|l|}
\hline & BR & AR & BR & AR & BR & AR \\
\hline Variables & OLS & OLS & REM & REM & FEM & FEM \\
\hline Lret & -0.0010 & -0.0102 & -0.0025 & -0.0024 & -0.0038 & -0.0038 \\
& $(0.0034)$ & $(0.0051)$ & $(0.0033)$ & $(0.0074)$ & $(0.0035)$ & $(0.0079)$ \\
\hline Lsize & $0.0235^{* * *}$ & $0.0235^{* *}$ & $0.0245^{* * *}$ & $0.0244^{*}$ & $0.0264^{* * *}$ & $0.0264^{*}$ \\
& $(0.0029)$ & $(0.0105)$ & $(0.0036)$ & $(0.0132)$ & $(0.0047)$ & $(0.0148)$ \\
\hline Lgrowth & -0.0121 & -0.0121 & -0.0106 & -0.0106 & -0.0090 & -0.0089 \\
& $(0.0080)$ & $(0.0171)$ & $(0.0087)$ & $(0.0201)$ & $(0.0100)$ & $(0.0218)$ \\
\hline Llev & $-0.1384^{* * *}$ & $-0.1384^{* * *}$ & $-0.1294^{* * *}$ & $-0.1293^{* * *}$ & $-0.1146^{* * *}$ & $-0.1146^{* *}$ \\
& $(0.0210)$ & $(0.0211)$ & $(0.0242)$ & $(0.0350)$ & $(0.0293)$ & $(0.0492)$ \\
\hline Constant & 0.6191 & 0.6191 & 0.6133 & 0.6133 & 0.6010 & 0.6010 \\
& $(0.0140)$ & $(0.0394)$ & $(0.0174)$ & $(0.0507)$ & $(0.0230)$ & $(0.0585)$ \\
\hline Observation & 418 & 418 & 418 & 418 & 418 & 418 \\
\hline R squared & 0.1716 & 0.1716 & 0.0977 & 0.0977 & 0.0991 & 0.0991 \\
\hline
\end{tabular}

${ }^{*} B F=$ Before Robust, $A R=$ After Robust, $O L S=$ Pooled OLS, REM = Random Effect Model, FEM = Fixed Effect Model, Standard error in parentheses

*** $p<0.01 ;{ }^{* *} p<0.05 ;{ }^{*} p<0.1$

It can be said that the final model suitable for ROA is Random Effect Model as it has shown better results in BPLM test. The variables that shows significant influence towards ROA is firm size and leverage even though the data has been run with Robust Standard Error test. With that, it can be said that the result of the objective is failed to reject the null hypotheses of $\mathrm{H} 2 \mathrm{a}$ and $\mathrm{H} 4 \mathrm{a}$ while for the other variables of retrenchment and growth opportunities, there were no signs of significance towards ROA. Hence with the results, the null hypotheses $\mathrm{H} 1 \mathrm{a}$ and $\mathrm{H} 3 \mathrm{a}$ can be rejected. 
INTERNATIONAL JOURNAL OF ACADEMIC RESEARCH IN ACCOUNTING, FINANCE AND MANAGEMENT SCIENCES

Vol. 11, No. 1, 2021, E-ISSN: 2225-8329 @ 2021 HRMARS

Table 2 Linear Regression Return on Equity (Robust)

\begin{tabular}{|l|l|l|l|l|l|l|}
\hline & BR & AR & BR & AR & BR & AR \\
\hline Variables & OLS & OLS & REM & REM & FEM & FEM \\
\hline Lret & 0.0091 & 0.0091 & 0.0091 & 0.0091 & 0.0095 & 0.0095 \\
& $(0.0106)$ & $(0.0083)$ & $(0.0107)$ & $(0.0083)$ & $(0.0117)$ & $(0.0093)$ \\
\hline Lgrowth & 0.0326 & 0.0326 & 0.0333 & 0.0333 & $0.0572^{*}$ & 0.0572 \\
& $(0.0252)$ & $(0.0361)$ & $(0.0255)$ & $(0.0363)$ & $(0.0340)$ & $(0.0577)$ \\
\hline Lsize & -0.1015 & -0.1015 & -0.1019 & -0.1019 & -0.1173 & -0.1173 \\
& $(0.0671)$ & $(0.0800)$ & $(0.0678)$ & $(0.0806)$ & $(0.0993)$ & $(0.0920)$ \\
\hline Llev & 0.0082 & 0.0082 & 0.0082 & 0.0082 & 0.0094 & 0.0094 \\
& $(0.0093)$ & $(0.0057)$ & $(0.0095)$ & $(0.0058)$ & $(0.0159)$ & $(0.0076)$ \\
\hline Constant & 3.0787 & 3.0787 & 3.0782 & 3.0782 & 3.0609 & 3.0609 \\
& $(0.0444)$ & $(0.0497)$ & $(0.0451)$ & $(0.0497)$ & $(0.0780)$ & $(0.0593)$ \\
\hline Observation & 418 & 418 & 418 & 418 & 418 & 418 \\
\hline R squared & 0.0153 & 0.0153 & 0.0164 & 0.0164 & 0.0169 & 0.0169 \\
\hline
\end{tabular}

${ }^{*} B F=$ Before Robust, $A R=$ After Robust, $O L S=$ Pooled OLS, REM $=$ Random Effect Model, FEM $=$ Fixed Effect Model, Standard error in parentheses

${ }^{* * *} p<0.01 ;{ }^{* *} p<0.05 ;{ }^{*} p<0.1$

As for return on equity, the suitable model is Random Effect Model as it failed to reject the Hausman Test null hypotheses. However, no variable shows any significant relationship with ROE and with that, the null hypotheses for this study of $\mathrm{H} 1 \mathrm{~b}, \mathrm{H} 2 \mathrm{~b}, \mathrm{H} 3 \mathrm{~b}$ and $\mathrm{H} 4 \mathrm{~b}$ can be rejected. After conducting the robust standard error test, firm size and leverage still remains as the variables that has significant influence to return on asset (ROA), while there are changes in return on equity (ROE) whereby growth is no longer significant to the variable.

Table 3 Linear Regression Tobin's Q (Feasible generalized least squares)

\begin{tabular}{|l|l|l|l|l|}
\hline & & & BFGLS & AFGLS \\
\hline Variables & OLS & REM & FEM & FEM \\
\hline Lret & 0.0123 & 0.0153 & 0.0147 & -0.0044 \\
& $(0.0184)$ & $(0.01318)$ & $(0.0131)$ & $(0.0042)$ \\
\hline Lsize & $-0.0401^{* * *}$ & -0.0262 & -0.0215 & $-0.0221^{* *}$ \\
& $(0.0162)$ & $(0.0169)$ & $(0.0178)$ & $(0.0111)$ \\
\hline Lgrowth & $0.6390^{* * *}$ & $0.4688^{* * *}$ & $0.4484^{* * *}$ & $0.3861^{* * *}$ \\
& $(0.0436)$ & $(0.0374)$ & $(0.0380)$ & $(0.01987)$ \\
\hline Llev & $-2.1790^{* * *}$ & $-1.8406^{* * *}$ & $-1.7874^{* * *}$ & $-1.3460^{* * *}$ \\
& $(0.1159)$ & $(0.1079)$ & $(0.1111)$ & $(0.0700)$ \\
\hline Constant & 0.7190 & 0.6812 & 0.6600 & 0.5668 \\
& $(0.0768)$ & $(0.0901)$ & $(0.0873)$ & $(0.0586)$ \\
\hline Observation & 418 & 418 & 418 & 418 \\
\hline R squared & 0.6221 & 0.5519 & 0.5519 & 0.5519 \\
\hline No. of Firms & 38 & 38 & 38 & 38 \\
\hline
\end{tabular}

*BFGLS = Before Feasible generalized least squares, $A F G L S=$ After Feasible generalized least squares, OLS $=$ Pooled OLS, REM = Random Effect Model, FEM = Fixed Effect Model

Standard error in parentheses

*** $p<0.01 ;{ }^{* *} p<0.05 ;{ }^{*} p<0.1$ 
Same as ROE, Tobin's Q is suitable with Fixed Effect Model as the Hausman Test rejected the null hypotheses. Nevertheless, the variables that shows significant relationship towards Tobin's $Q$ is firm size, growth opportunity and leverage. With that the null hypotheses for $\mathrm{H} 2 \mathrm{c}, \mathrm{H} 3 \mathrm{c}$ and $\mathrm{H} 4 \mathrm{c}$ is failed to reject while the null hypotheses of $\mathrm{H} 1 \mathrm{C}$ can be rejected as the main independent variable retrenchment is not significant with Tobin's Q.

\section{Discussion and Conclusion}

From the data analysed above, it can be concluded that them main variable of this study which the retrenchment strategy has no significant relationship with any of the firm performance of return on asset (ROA), return on equity (ROE) and Tobin's $Q$ and this rejects all null hypotheses of having positive and significant relationship with the firm performance. In addition, the result deducts the Agency Theory about the benefit of lay-offs for to obtain better performance for the company.

As for the controlled variables, the only variables that has significant influence towards ROA is firm size, and leverage. For ROE however, no variable shows any significance towards it and last for Tobin's $Q$, all variables of firm size, growth opportunity and leverage show significant relationship with Tobin's Q.

As this study follows previous research such as Ung, Brahmana, \& Puah (2018) and Hillier, Marshall, McColgan, \& Werema (2007), this study contributes other dependant variable that is listed outside from Accounting-Based Measurements which is Tobin's $Q$ as it represents a type of Market-Based Measurements for identifying firm performance.

In the matter of theoretical aspect, Robert T. Kleiman stated that investors are rewarded when companies decreased their employees because operating costs are lowered, which in theory may lead to better profits. This study shows support towards the Agency Theory regarding retrenchment practices being implemented in the company. Investors of the chosen companies can be pleased to know that management undertaking layoffs can achieve the objectives which is to please shareholders and to maximize their wealth.

\section{Limitation and Direction for Future Research Data Constraint}

The limit of this study is that it is only focused on public listed construction companies in Malaysia. Without the extended information from private companies, the result stays obsolete due to the reason that it is not the result of a whole sector. This is limitation is due to the information blocked or kept private and confidential.

\section{Limited Area Coverage}

Other limitation includes the area coverage of this study which is Malaysia. Although the result is good enough for covering one area, a considerable coverage may also lead to substantial result such as including other ASEAN countries for example Vietnam, Singapore, Thailand and many more.

\section{Recommendations}

The data from this study was taken from the period 2008 - 2018. For future considerations this period may be extended to ten years or above. Other than that, other sectors can also be included as to 
INTERNATIONAL JOURNAL OF ACADEMIC RESEARCH IN ACCOUNTING, FINANCE AND MANAGEMENT SCIENCES

Vol. 11, No. 1, 2021, E-ISSN: 2225-8329 @ 2021 HRMARS

compare the results of different sectors such as manufacturing. Moreover, future updates can also include private companies as to gain result of a whole sector. Lastly, more performance ratios can be used to determine a relationship of retrenchment to firm's performance.

\section{References}

Al-Matari, E. M., Al-Swidi, A. K., \& Fadzil, F. H. B. (2014). The Measurements of Firm Performance's Dimensions. Asian Journal of Finance \& Accounting, 6(1), 24.

Anastasia. (2015) https://www.cleverism.com/effective-corporate-turnaround-strategies/

Barker, V., \& Mone , M. (1994). Retrenchment: Cause of turnaround or consequence of decline? Strategic Management Journal, 15: 395-405.

Baron, J. N., \& Kreps, D. M. (1999). Strategic Human Resources: Frameworks for General Management. New York: Wiley

Bozec, R., Dia, M., \& Bozec, Y. (2010). Governance - performance relationship: A Reexamination Using Technical Efficiency Measures. British Journal of Management, 21, 684-700.

Budros, A. (1999). A conceptual framework for analyzing why organizations downsizing. Organization Sciences, 10(1), 69-82

Bititci, U., Carrie, A., \& McDevitt, L. (1997). Integrated performance measurement systems: A development guide. International Journal of Operations \& Production Management, 17(5), 522-534

Castrogiovanni, G., \& Bruton, G. (2000). Business turnaround processes following acquisitions: reconsidering the role of retrenchment. Journal of Business Research, 48, 25-34.

David, F. (2013). Strategic management: A competitive advantage approach, concepts and cases. Harlow,England: Pearson Prentice Hall.

Demirbag, M., Tatoglu, E., Tekinus, M., \& Zaim, S. (2006). An analysis of the relationship between TQM implementation and organizational performance: evidence from Turkish SMEs. Journal of Manufacturing Technology Management, 17(6), 829847.

Denis, D., Denis, D., \& Yost, K. (2002). Global diversification, industrial diversification, and firm value. Journal of Finance, 57(5), 1951-1979

DeWitt, R. (1998). Firm, industry, and strategy influences on choice of downsizing approach. Strategic Management Journal, 19(1): 59-79.

Dodge, H., Fullerton, S., \& Robbins, J. (1994). Stage of the organizational life cycle and competition as mediators of problem perception in small businesses. Strategic Management Journal, 15(2), 121- 134.

Ellis, J., (1998). The downside of downsizing, Boston Globe. p. 11:A15.

Elvin, P., \& Abdul Hamid, N. I. N. (2015). Ownership Structure, Corporate Governance and Firm Performance. Corporate Governance: An International Review, 23(6), 469-471.

Fisher, G., Lee, J., \& Johns, L. (2004). An Exploratory Study of Company Turnaround in Australia and Singapore Following the Asia Crisis. Asia Pacific Journal of Management, 21(12), 149-170.

Ganguli, S. K., \& Agrawal, S. (2009). Ownership structure and firm performance: An empirical study on listed Mid-Cap Indian Companies.

Hambrick, D., \& D’Aveni, R. (1988). Large corporate failures as downward spirals. 
INTERNATIONAL JOURNAL OF ACADEMIC RESEARCH IN ACCOUNTING, FINANCE AND

MANAGEMENT SCIENCES

Vol. 11, No. 1, 2021, E-ISSN: 2225-8329 @ 2021 HRMARS

Administrative Science Quarterly, 33(1), 1-23.

Haniffa, R., \& Hudaib, M. (2006). Corporate governance structure and performance of Malaysian listed companies. Journal of Business Finance and Accounting, 33(7-8), 1034-1062.

Hillier, D., Marshall, A., McColgan, P., \& Werema, S. (2007). Employee layoffs, shareholder wealth and firm performance: Evidence from the UK. Journal of Business Finance and Accounting, 34(3-4), 467-494.

Hutchinson, M., \& Gull, F. (2004). Investment opportunity set, corporate governance practices, and firm performance. Journal of Corporate Finance, 10(1), 595-614.

Ibrahim, Haslindar, \& AbdulSamad, F. A. (2011). Corporate governance mechanisms And performance of public-listed family-ownership in Malaysia. International Journal of Economics and Finance, 3(1), 105-115.

Imran, M. (2014). Impact of Capital Structure on Firm Performance: Evidence from Pakistani Firms. (September).

Joh, S. W. (2003). Corporate governance and firm profitability evidence from Korea before the economic crisis. Journal of Financial Economics, 68(2), 287-322.

Koufopoulos, D., Zoumbos, V., Argyropoulou, M., \& Motwani, J. (2008). Top management team and corporate performance: a study of Greek firms. Team Performance Management, 14(8), 340-363.

Kapopoulos, P., \& Lazaretou, S. (2007). Corporate ownership structure and firm performance: evidence from Greek firms. Corporate Governance, 15(2), 144-159.

Kapopoulos, P., \& Lazaretou, S. (2009). Does Corporate Ownership Structure Matter for Economic Growth ? A Cross- Country Analysis. Managerial and Decision Economic, 30, 155172.

Klapper, L., \& Love, I. (2002). Corporate governance, investor protection, and performance in emerging markets. Washington, DC. United States: World Bank. Mimeographed document.

Khanna, T., \& Palepu, K. (2000). Is group affiliation profitable in emerging markets? An analysis of diversified Indian business groups. Journal of Finance, 55(2), 867-891.

Kwamboka, N. E., \& Nassiuma, B. K. (2017). Employee Downsizing Strategies and Firm Performance: Evidence From the Kenyan Context Employee Downsizing Strategies and Firm Performance: Evidence From the Kenyan Context. Journal of Human Resource and Leadership, 2(7), 58-68.

Lebas, M. (1995). Performance measurement and performance management, International Journal of Production Economics, 41(1-3), 23-35.

Lee, K., Hooy, C., \& Hooy, G. (2012). The Value impact of international and industrial diversifications on publisted-listed firms in Malaysia. Emerging Markets Review, 13(3),366-380.

Lim, D., Celly, N., Morse, E., \& Rowe, W. (2013). Rethinking the effectiveness of asset and cost retrenchment: The contingency effects of a firm's rent creation mechanism. Strategic Management Journal, 4(1), 42-61

Lins, K., \& Servaes, H. (2002). Is Corporate Diversification Beneficial in Emerging Market? Financial Management, 31(2), 5-31

Love, E., \& Nohria, N. (2005). Reducing Slack: The Performance Consequences of Downsizing by Large Industrial Firms, 1977-93. Strategic Management Journal, 26(12), 1087-110.

Madu, C., Aheto, J., Kuei, C., \& Winokur, D. (1996). Adoption of strategic total quality management 
INTERNATIONAL JOURNAL OF ACADEMIC RESEARCH IN ACCOUNTING, FINANCE AND

MANAGEMENT SCIENCES

Vol. 11, No. 1, 2021, E-ISSN: 2225-8329 @ 2021 HRMARS

philosophies Multi-criteria decision analysis model. International Journal of Quality and Reliability Management,13(3),57 - 72

Mashayekhi, B., \& Bazazb, M. S. (2008). Corporate governance and firm performance in Iran, 4(2), 156-172.

McKee-Ryan , F. M., \& Kinicki, A. J. (2002). Coping job loss: a life-facet perspective. International Review of Industrial and Organizational Psychology, 17, 1-29.

McKinley, W. (1995). Organizational downsizing: constraining, cloning, learning, The Academy of Management Executive, 9(3), 32-44.

McKinley, W. (2001). A socio-cognitive interpretation of organizational Downsizing. Academy of Management Review, 25(1), 227-243.

Miles, G., Snow, C., \& Sharfman, M. (1993). Industry variety and performance. Strategic Management Journal, 14(3), 163-177.

Mone, M. A. (1997). How we got along after the downsizing: post-downsizing trust as a double- edged sword. Public Administration Quarterly, 21(3), 309-336.

Morrow, J., Johnson, R., \& Busenitz, L. (2004). The effects of cost and asset retrenchment on firm performance: the overlooked role of a firm's competitive environment. Journal of Management, 30(2), 189-208

Nawaz, K., \& Ahmad, N. (2017). The Effect of Corporate Governance and Capital Structure on Firms' Performance: Investigation on Petroleum Sector in Pakistan. 1(15), 51-68.

Neely, A., Gregory, M., \& Platts, K. (2005). Performance measurement system design: A literature review and research agenda. International Journal of Operations \& Production Management, 25(12), 1128-1263.

Nuryanah, S., \& Islam, S. M. N. (2011). Corporate governance and performance: Evidence from an Emerging Market. Malaysian Accounting Review, 10(1), 17-42.

O'Neill, H. (1986). Turnaround and recovery: What strategy do you need? Long Range Planning, 19(1), 80-88

Pearce, J., \& Robbins, K. (2008). Strategic transformation as the essential last step in the process of business turnaround. Business Horizons, 51(2), 121-30.

Pham, T. T. K. (2016). Research on the Relationship between Corporate Governance and Firm Performance: Empirical Evidence from Companies Listed on the Stock Exchange in Vietnam. International Journal of Management and Applied Research, 3(4), 172-183

Robbins, D., \& John, A. (1993). Entrepreneurial Retrenchment among Small Manufacturing firms. Journal of Business Venturing, 8(4), 301-318.

Robbins, D., \& Pearce, J. (1992). Turnaround: retrenchment and recovery. Strategic Management Journal, 13(4): 287-309

Rouf, M. A. (2011). The relationship between corporate governance and value of the firm in developing countries: Evidence from Bangladesh. The International Journal of Applied Economics and Finance, 5(3), 237-244.

Schendel, D., Patton, G., \& Riggs, J. (1976). Corporate turnaround strategies: A study of profit decline and recovery. Journal of General Management, 3(spring): 3-

11.

Schmitt, A., \& Raisch, S. (2013). Corporate Turnarounds and Recovery: The Duality of Retrenchment. Journal of Management Studies, 50(7), 1216-1244

Scott, J. H. (2012). A theory of optimal capital structure. 7(1), 33-54. 
Shan, Y. G., \& Mclver, R. P. (2011). Corporate governance mechanisms and financialperformance in China: panel data evidence on listed non-financial companies. Asia Pacific Business Review, 17(3), 301-324.

Sharma, B., \& Gadenne, D. (2002). An inter-industry comparison of quality management practices and performance. Managing Service Quality, 12(6), $394-404$

Snow, C., \& Hrebiniak, L. (1980). Strategy, distinctive competence, and organizational performance. Administrative Science Quarterly, 25(2), 317-336

THUY, P. B. G., \& DUC, V. H. (2017). Corporate Governance and Firm's Performance: Empirical Evidence from Vietnam. Journal of Economics Development, 218(April 2013), 62-77.

Tsai, C. F., Wu, S. L., Wang, H. K., \& Huang, I. C. (2006). An empirical research on the institutional theory of downsizing: Evidence from MNC's subsidiary companies in Taiwan. Total Quality Management and Business Excellence, 17(5), 633-654.

Ung, L., Brahmana, R., \& Puah, C.-H. (2018). Firm Performance, Retrenchment Strategy and Ownership Structure: Evidence from Public Listed Companies in Malaysia. Int. Journal of Business Science and Applied Management, 13(1), 1-17.

Vo, D. H., \& Nguyen, T. M. (2014). The Impact of Corporate Governance on Firm Performance: Empirical Study in Vietnam. International Journal of Economics and Finance, 6(6).

Vu, N. H., \& Nguyen, T. (2017). Impacts of corporate governance on firm performance Empirical study of listed Singaporean companies. (May).

Wahla, K.-U.-R., Shah, S. Z. A., \& Hussain, Z. (2012). Impact of ownership structure on firm \ performance evidence from non-financial listed companies at Karachi Stock Exchange. International Research Journal of Finance and Economics, 84, 6-13.

Zeitun, R., Tian, G. (2007), Capital structure and corporate performance: evidence from Jordan, Australasian Accounting Business and Finance Journal, 1: 40-53. 